\title{
Sucrose-dependent Cell Adherence and Cariogenicity of Serotype $c$ Streptococcus mutans
}

\author{
By TOSHIHIKO KOGA, HIDEHARU ASAKAWA, NOBUO OKAHASHI \\ AND SHIGEYUKI HAMADA* \\ Department of Dental Research, National Institute of Health, 2-10-35 Kamiosaki, Shinagawa-ku, \\ Tokyo 141, Japan
}

(Received 30 December 1985; revised 22 April 1986)

\begin{abstract}
Four strains of serotype $c$ Streptococcus mutans differing in glucosyltransferase (GTase) and fructosyltransferase (FTase) activities were examined. These strains had been made resistant to streptomycin. FTase activity of an S. mutans clinical variant, MT6801R, which forms large mucoid colonies on sucrose-containing agar, was considerably higher than that of a typical serotype $c$ strain, MT8148R, which forms small, rough colonies on the same agar. Two mutants, NG14 and NG7183, were induced from strain MT6801 R by $N$-methyl- $N^{\prime}$-nitro- $N$-nitrosoguanidine, and were found to be streptomycin-resistant. GTase and FTase activities of mutant NG14 were similar to those of the typical serotype $c$ strain, while in mutant NG7183 the two enzyme activities were very low. Growing cells of these strains (except NG7183) adhered firmly to a glass surface in sucrose broth. Resting cells of all strains attached in small numbers to salivacoated hydroxyapatite in the absence of sucrose. On the other hand, the presence of sucrose markedly enhanced the attachment of cells of strains MT8148R, MT680I R and NG14, but not NG7183. Cell-surface hydrophobicity and acid production of all strains were similar. Both strain MT8148R and NG14 colonized tooth surfaces and produced significant dental caries in specific-pathogen-free rats. Strain MT6801R had lower colonization ability and cariogenicity when compared with strains MT8148R and NG14. Furthermore, mutant NG7183 was able to colonize the tooth surfaces in small numbers, but failed to cause dental caries. These results indicate that sucrose-dependent cell adherence mediated by de novo glucan synthesis is necessary for the accumulation of serotype $c S$. mutans cells on the tooth surface and the induction of dental caries.
\end{abstract}

\section{INTRODUCTION}

Streptococcus mutans has been strongly implicated as a causative organism of dental caries. Strains of $S$. mutans are divided serologically into eight types, $a$ to $h$. Among these serotypes, serotype $c$ strains are most frequently isolated from human dental plaque (Hamada \& Slade, 1980; Cohen et al., 1983).

$S$. mutans produces both water-soluble and water-insoluble polysaccharides from sucrose by the action of multiple forms of glucosyltransferase (GTase) and fructosyltransferase (FTase) (Hamada \& Slade, 1980). De novo synthesis of water-insoluble glucan is involved in the firm attachment and accumulation of serotype $d$ and $g S$. mutans to tooth surfaces (Mukasa \& Slade, 1973; Hamada, 1977; Koga \& Inoue, 1978). In addition, the glucan firmly coats the tooth surface, forming a barrier which prevents the diffusion of acids produced by these serotypes.

\footnotetext{
Abbreviations: FTase; fructosyltransferase, GTase; glucosyltransferase, GTase-S; water-soluble glucansynthesizing enzyme, GTase-I; water-insoluble glucan-synthesizing enzyme, MS; mitis-salivarius, BHI; Brain Heart Infusion, PAS; periodic acid-Schiff, S-HA; saliva-coated hydroxyapatite; MNNG, $N$-methyl- $N^{\prime}$-nitro- $N$ nitrosoguanidine.
} 
However, GTases of serotype $c S$. mutans are immunologically and biochemically different from the enzymes of serotypes $d$ and $g$ (Smith \& Taubman, 1977; Russell, 1979a; Tsumori et al., 1983). Moreover, serotype $c S$. mutans produces considerably less water-insoluble glucan than serotypes $d$ and $g$. The biochemical and morphological properties of water-insoluble glucan of the former are very different from those of the glucan of the latter (Yakushiji et al., 1984).

Therefore, the role of polysaccharides in cell adherence and cariogenicity of serotype $c S$. mutans should be clarified. In this study, we selected two clinical strains of serotype $c S$. mutans and two mutants derived from one of the strains. The mutants differed in their ability to produce glucan and fructan; their ability to adhere to hard surfaces and to form acid, as well as their cariogenicity in rats were compared. In addition, the properties of cell-free and cell-bound proteins of these strains are discussed in terms of their adherence and cell-surface hydrophobicity.

\section{METHODS}

Bacterial strains. The source of $S$. mutans MT8148 (serotype $c$ ) and MT6801 (serotype $c$ ) was described by Okahashi et al. (1984). Spontaneous streptomycin-resistant mutants from strains MT8148 and MT6801 were isolated and termed MT8148R and MT6801 R, respectively. These strains showed the same colonial morphology on mitis-salivarius (MS) agar (Difco), and the same biochemical properties, as their parent strains. In the present study, we used these streptomycin-resistant strains together with two mutants (NG14 and NG7183) induced by $\mathrm{N}$ methyl- $N^{\prime}$-nitro- $N$-nitrosoguanidine (MNNG) (Adelberg et al., 1965) and differing in colonial morphology on MS agar from strain MT6801R. These mutants were confirmed to be resistant to streptomycin.

Quantitative determination of glucan and fructan. Strains of S. mutans were grown for $18 \mathrm{~h}$ at $37^{\circ} \mathrm{C}$ in Brain Heart Infusion (BHI; Difco) broth. The culture was then centrifuged and the cell-free culture supernatant was adjusted to $\mathrm{pH} 6.0$ with $1 \mathrm{M}-\mathrm{NaOH}$. The cells were washed with $0.1 \mathrm{M}$-potassium phosphate buffer, $\mathrm{pH} 6.0$, and suspended in the same buffer (volume equivalent to that of the broth in which they were grown originally). GTase and FTase activities were measured by the method of Koga \& Inoue (1981). For the measurement of GTase activity, the enzyme was allowed to react with $10 \mathrm{mM}-\left[{ }^{14} \mathrm{C}\right.$-glucose $]$ sucrose $\left[0.4 \mathrm{Ci} \mathrm{mol}^{-1}\left(14.8 \mathrm{GBq} \mathrm{mol}^{-1}\right) \mathrm{New}\right.$ England Nuclear] and $20 \mu \mathrm{M}$-dextran $\mathrm{T} 10$ in $20 \mu \mathrm{l} 0.1 \mathrm{M}$-potassium phosphate buffer, $\mathrm{pH} 6.0$. For the measurement of FTase activity, the enzyme was allowed to react with $10 \mathrm{mM}-\left[{ }^{14} \mathrm{C}\right.$-fructose $]$ sucrose $\left[0.4 \mathrm{Ci} \mathrm{mol}^{-1}\left(14.8 \mathrm{GBq} \mathrm{mol}^{-1}\right)\right.$ New England Nuclear] in 0.1 M-potassium phosphate buffer, pH 6.0. After incubation at $37^{\circ} \mathrm{C}$ for $1 \mathrm{~h}$, the reaction mixture was spotted on a filter paper square $(15 \times 15 \mathrm{~mm}$, no. 514, Toyo Roshi, Tokyo, Japan). The squares were washed three times with methanol and dried. Radioactivity retained on the paper squares was measured with a Packard model 3385 scintillation spectrometer to quantify the polysaccharide synthesized. One unit (U) of GTase and FTase activities was defined as the amount of enzyme that transferred $1 \mu \mathrm{mol}$ of sucrose to polysaccharide $\min ^{-1}$ under the conditions described above.

Synthesis of polysaccharide by growing cells was determined as follows. S. mutans was cultured in BHI broth containing $1 \%(\mathrm{w} / \mathrm{v})$ sucrose for $18 \mathrm{~h}$ at $37^{\circ} \mathrm{C}$. Three fractions of polysaccharides, (i) extracellular, water-soluble, (ii) I $\mathrm{M}-\mathrm{NaOH}$-soluble, cell-associated and (iii) $1 \mathrm{M}-\mathrm{NaOH}$-insoluble, cell-associated, were prepared from the culture according to the procedure of Freedman \& Tanzer (1974). The glucan and fructan contents of these fractions were quantified differentially by the cold anthrone method (Handel, 1967), using glucose and fructose as the standards.

Adherence of growing cells to a glass surface in sucrose broth. S. mutans was grown at $37^{\circ} \mathrm{C}$ at a $30^{\circ}$ angle for $18 \mathrm{~h}$ in $3 \mathrm{ml} \mathrm{BHI}$ broth containing $1 \%(\mathrm{w} / \mathrm{v})$ sucrose. The number of adherent cells was determined turbidimetrically and expressed as a percentage of the total cell mass (percentage cell adherence) as described by Hamada $e t$ al. (1981).

Adsorption of resting cells to saliva-coated hydroxyapatite. Spheroidal hydroxyapatite beads $(5 \mathrm{mg})(\mathrm{BDH})$ were incubated with $160 \mu \mathrm{l}$ clarified whole saliva for $1 \mathrm{~h}$ at $37^{\circ} \mathrm{C}$, and washed three times with buffered $\mathrm{KCl}$ (Eifert et al., 1984). S. mutans was grown at $37^{\circ} \mathrm{C}$ for $18 \mathrm{~h}$ in BHI broth containing $\left[6-{ }^{-3} \mathrm{H}\right]$ thymidine $\left[21.0 \mathrm{Ci} \mathrm{mmol}^{-1}\right.$ $\left(777 \mathrm{GBq} \mathrm{mmol}^{-1}\right)$ Amersham] at a final concentration of $10 \mu \mathrm{Ci} \mathrm{ml}^{-1} \cdot\left[{ }^{3} \mathrm{H}\right]$ Thymidine-labelled bacteria $(2 \times$ $\left.10^{8}\right)$ were allowed to react with the saliva-coated hydroxyapatite beads $(5 \mathrm{mg})$ in the presence or absence of $1 \%$ $(w / v)$ sucrose in $160 \mu \mathrm{l}$ buffered $\mathrm{KCl}$ (Eifert et al., 1984). After mixing with a micro-mixer (Taiyo Kagaku Kogyo, Tokyo, Japan) at $37^{\circ} \mathrm{C}$ for $30 \mathrm{~min}$, the reaction mixtures in microtitre plates were allowed to stand at $37^{\circ} \mathrm{C}$ for 0.5 to $6.5 \mathrm{~h}$. After incubation, the beads were washed three times in buffered $\mathrm{KCl}$. The radioactivity associated with the S-HA beads was then determined. The number of bacteria adsorbed was determined from the calculated specific radioactivity of the bacteria.

Hydrophobicity. S. mutans strains were grown at $37^{\circ} \mathrm{C}$ for $18 \mathrm{~h}$ in BHI broth. The relative surface hydrophobicity of the cells was determined by their adsorption to hexadecane and their aggregation in salt solution. The ability of the strains to adsorb to hexadecane was estimated as described by Rosenberg et al. (1980). 
The cells were washed twice and suspended in PUM buffer (Rosenberg et al., 1980) to an OD $_{550}$ of 0.6. Triplicate samples $(3 \mathrm{ml})$ of the bacterial suspensions were placed in test-tubes, and $300 \mu \mathrm{l}$ hexadecane was added. The tubes were then mixed with a vortex mixer for $1 \mathrm{~min}$ and allowed to stand until the phases separated. The $\mathrm{OD}_{550}$ of the lower aqueous phase was measured. Adsorption was calculated as the percentage loss in optical density relative to that of the initial cell suspension. Salt aggregation ability was determined by the procedure of Fives-Taylor \& Thompson (1985). Cells were washed twice and suspended in 2 mM-potassium phosphate buffer, pH 6.8, to a concentration of $4 \times 10^{9}$ cells $\mathrm{ml}^{-1}$. Dilutions of ammonium sulphate, $\mathrm{pH} 6.8$, from 4.0 to $0.2 \mathrm{M}$ were made in $2 \mathrm{~mm}$-potassium phosphate buffer, $\mathrm{pH} 6.8$, in $0.2 \mathrm{M}$ increments. The bacterial suspensions ( $30 \mu \mathrm{l})$ were added to $30 \mu \mathrm{l}$ of the appropriate salt dilution in 96-well, V-bottomed microtitre plates. The plates were rocked gently for $2 \mathrm{~min}$ at room temperature, and aggregation was read macroscopically. The data are represented as the lowest ammonium sulphate concentration causing bacterial aggregation.

SDS-PAGE. S. mutans strains were grown in dialysate medium of BHI broth at $37^{\circ} \mathrm{C}$ for $18 \mathrm{~h}$. The cell-free culture supernatant was collected by centrifugation at $10000 \mathrm{~g}$ for $20 \mathrm{~min}$ at $4{ }^{\circ} \mathrm{C}$. Extracellular proteins were precipitated from the culture supernatant by adding solid ammonium sulphate to $50 \%$ saturation. The precipitate was collected by centrifugation, dissolved in $5 \mathrm{~mm}$-potassium phosphate buffer, $\mathrm{pH} 6 \cdot 8$, and dialysed against the buffer. The concentrated culture supernatant was incubated at $37^{\circ} \mathrm{C}$ for $5 \mathrm{~min}$ in $10 \mathrm{~mm}$-Tris/ $\mathrm{HCl}$ buffer, $\mathrm{pH} 6.8$, containing $2 \%(\mathrm{w} / \mathrm{v})$ SDS and $1 \%(\mathrm{w} / \mathrm{v}) 2$-mercaptoethanol. The whole cells $\left(50 \mathrm{mg}\right.$ dry weight $\left.\mathrm{ml}^{-1}\right) \mathrm{were}^{-1}$ suspended in $2 \%(\mathrm{w} / \mathrm{v})$ SDS and $1 \%(\mathrm{w} / \mathrm{v}) 2$-mercaptoethanol and heated at $100{ }^{\circ} \mathrm{C}$ for $30 \mathrm{~min}$. The SDS extract was clarified by centrifugation. SDS-polyacrylamide slab gels were prepared as described by Laemmli (1970). The culture supernatant $\left(0.5 \mathrm{mg}\right.$ protein) and the cell extract $(30 \mu \mathrm{l})$ were electrophoresed at $10 \mathrm{~mA}$ per gel at $4{ }^{\circ} \mathrm{C}$ for $16 \mathrm{~h}$ using a $7 \cdot 5 \%(\mathrm{w} / \mathrm{v})$ resolving and a $3 \%(\mathrm{w} / \mathrm{v})$ stacking gel $(14 \times 11 \times 0.2 \mathrm{~cm})$ containing $0.1 \%(\mathrm{w} / \mathrm{v}) \mathrm{SDS}$. Ovalbumin $\left(M_{\mathrm{r}} 43000\right)$, catalase (60000), bovine serum albumin (67000), phosphorylase B $(94000)$ and ferritin (220000) were used as $M_{\mathrm{r}}$ standards. Proteins were stained with Coomassie brilliant blue R-250. To detect GTase and FTase activities, the gels were incubated at $37^{\circ} \mathrm{C}$ for $18 \mathrm{~h}$ with $5 \%(\mathrm{w} / \mathrm{v})$ sucrose and $0 \cdot 1 \%(\mathrm{w} / \mathrm{v})$ dextran T10 (Pharmacia) in $50 \mathrm{~mm}$-potassium phosphate buffer, pH 6.0. In addition, the gels were incubated at $37{ }^{\circ} \mathrm{C}$ for $48 \mathrm{~h}$ with $5 \%(\mathrm{w} / \mathrm{v})$ raffinose in $50 \mathrm{~mm}$-potassium phosphate buffer, pH 6.0, to detect FTase (Russell, 1979a). Polysaccharides formed were stained with the periodic acid-Schiff (PAS) reagent by the method of Zacharius $e t$ al. (1969).

Electrophoretic blotting. The culture supernatant $(0.5 \mathrm{mg}$ protein) was electrophoresed in SDS-polyacrylamide slab gels as described above, and transferred to a nitrocellulose sheet by the electrophoretic blotting technique (Burnette, 1981). The sheet was treated with a monoclonal antibody which reacted with a water-soluble glucansynthesizing enzyme (GTase-S) purified by the method of Sato et al. (1984). The antibody bound to the immobilized replica proteins on the sheet was detected by solid-phase immunoassay with horseradish peroxidaseconjugated rabbit anti-mouse immunoglobulin (Furuta et al., 1983).

Acid production. S. mutans strains were grown aerobically and anaerobically (Gas Pack; BBL) for $48 \mathrm{~h}$ in BHI broth supplemented with $1 \%(\mathrm{w} / \mathrm{v})$ glucose. Growth of the culture was measured as the $\mathrm{OD}_{550}$. The final pH of the broth was measured with a PHM 82 standard pH meter (Radiometer). The amount of lactic acid in the culture supernatant was determined by the method of Gutmann \& Wahlefeld (1974).

Cariogenicity. The ability of streptomycin-resistant $S$. mutans strains to induce dental caries in specificpathogen-free Sprague-Dawley rats was determined as described by Ooshima et al. (1983). In brief, weanling rats ( $15 \mathrm{~d}$ old) were given both an ordinary powdered diet MF (Oriental Yeast Co., Osaka, Japan) containing tetracycline $\left[4 \mathrm{mg}\left(\mathrm{g} \mathrm{diet}^{-1}\right]\right.$ and deionized water containing penicillin $\mathrm{G}\left[4000 \mathrm{U}(\mathrm{ml} \text { water })^{-1}\right]$ ad libitum. After treatment with antibiotics for $2 \mathrm{~d}, S$. mutans cells $\left(1 \times 10^{9}\right)$ were orally inoculated in groups of 10 to 12 rats on six consecutive days; the rats were then maintained on diet 2000 containing $56 \%(\mathrm{w} / \mathrm{w})$ sucrose (Keyes \& Jordan, 1964). Dental plaque samples were obtained from the surfaces of the molar teeth of the rats using a cotton applicator, which was then shaken in a test tube containing $1 \mathrm{ml}$ sterile saline $(0.85 \% \mathrm{NaCl})$. Suspended samples $(0.1 \mathrm{ml})$ were spread on MS agar containing streptomycin $\left(500 \mu \mathrm{g} \mathrm{ml}^{-1}\right)$. The plates were incubated at $37^{\circ} \mathrm{C}$ for $2 \mathrm{~d}$, and the number of colonies recovered was determined. At $86 \mathrm{~d}$ after the initial infection, the animals were killed, and the jaws were removed. The caries lesions were scored by the modification by Ooshima et al. (1983) of the method of Keyes (1944).

\section{RESULTS}

\section{Colonial morphology and polysaccharide production}

$S$. mutans MT8148R, a typical serotype $c$ strain, formed small, raised, rough, pale blue colonies on MS agar, while $S$. mutans MT6801R, a clinical variant from human dental plaque, formed large mucoid colonies on the same agar (Fig. $1 a, b$ ). Two mutants (NG14 and NG7183), differing in colonial morphology from the parent strain MT6801R, were induced by MNNG. 

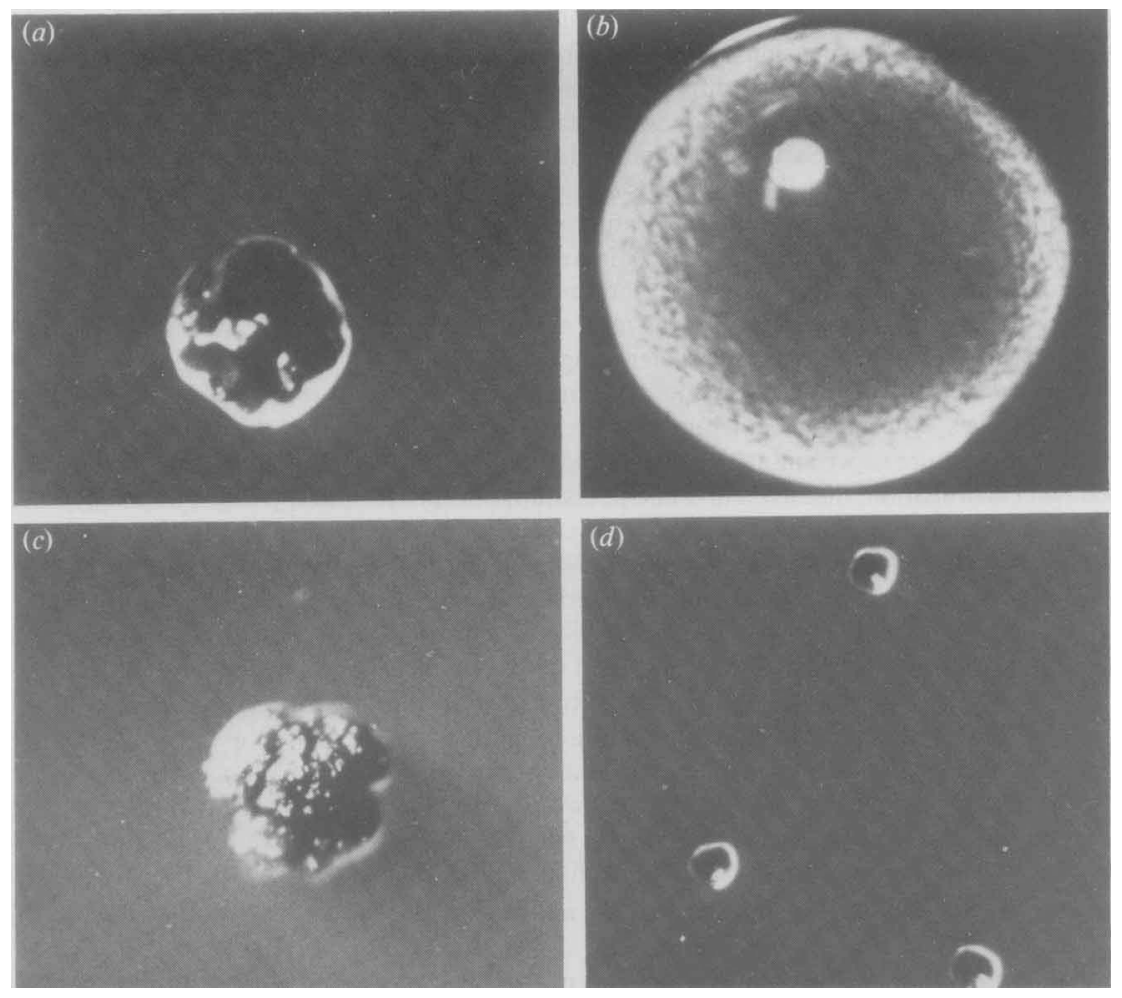

Fig. 1. Colonial morphology of serotype $c S$. mutans strains on MS agar. (a) Strain MT8148R; (b) strain MT6801R; (c) strain NG14; (d) strain NG7183.

Table 1. GTase and FTase activities of serotype c S. mutans strains

Strains of $S$. mutans were grown at $37^{\circ} \mathrm{C}$ for $18 \mathrm{~h}$ in BHI broth. Cell-free and cell-bound enzyme activities were determined as described in Methods. Values are the mean \pm SD of triplicate cultures.

\begin{tabular}{|c|c|c|c|c|}
\hline \multirow[b]{3}{*}{ Strain } & \multicolumn{4}{|c|}{ Enzyme activity $\left(\mathrm{mU} \mathrm{ml} \mathrm{m}^{-1}\right)$} \\
\hline & \multicolumn{2}{|c|}{ Cell-free } & \multicolumn{2}{|c|}{ Cell-bound } \\
\hline & GTase & FTase & GTase & FTase \\
\hline MT8148R & $15 \cdot 7 \pm 4.8$ & $21 \cdot 6 \pm 1 \cdot 7$ & $1.4 \pm 0.5$ & $0.8 \pm 0.2$ \\
\hline MT6801R & $12.9 \pm 1.6$ & $84 \cdot 4 \pm 2 \cdot 1$ & $1 \cdot 1 \pm 0 \cdot 1$ & $2 \cdot 3 \pm 0 \cdot 6$ \\
\hline NG14 & $11 \cdot 2 \pm 2.4$ & $9.9 \pm 0.4$ & $1 \cdot 1 \pm 0 \cdot 1$ & $0.5 \pm 0.1$ \\
\hline NG7183 & $0 \cdot 8 \pm 0 \cdot 1$ & 0 & $0.1 \pm 0.1$ & 0 \\
\hline
\end{tabular}

The colonial morphology of mutant NG14 was similar to that of the typical serotype $c S$. mutans strain MT8148R, while mutant NG7183 formed significantly smaller smooth colonies (Fig. $1 c, d)$.

GTase and FTase activities of the above strains grown in BHI broth are shown in Table 1 . Most of the activity of the two enzymes was located extracellularly in glucose broth. The FTase activity of strain MT6801R was considerably higher than that of strain MT8148R. These findings indicate that the mucoid material of the MT6801R colonies should be fructan. The GTase activity of mutant NG14 was similar to that of the parent strain MT6801R, and the FTase activity of the mutant was far lower than that of the parent strain. In the mutant NG7183, activities of both enzymes were very low. 
Table 2. Extracellular and cell-associated polysaccharides produced by serotype $c$ $S$. mutans strains grown in sucrose broth

Strains of $S$. mutans were grown at $37^{\circ} \mathrm{C}$ for $18 \mathrm{~h}$ in BHI broth containing $1 \%(\mathrm{w} / \mathrm{v})$ sucrose. Three polysaccharide fractions were prepared from the culture by the procedure of Freedman \& Tanzer (1974). The glucan and fructan contents of these fractions were quantified differentially by the cold anthrone method. Values are the mean \pm SD of triplicate cultures.

\begin{tabular}{|c|c|c|c|c|c|c|}
\hline \multirow[b]{3}{*}{ Strain } & \multicolumn{6}{|c|}{ Polysaccharide synthesized $\left(\mathrm{mg} \mathrm{ml}^{-1}\right)$} \\
\hline & \multicolumn{2}{|c|}{$\begin{array}{l}\text { Extracellular, } \\
\text { water-soluble }\end{array}$} & \multicolumn{2}{|c|}{$\begin{array}{l}1 \mathrm{M}-\mathrm{NaOH}- \\
\text { soluble, cell- } \\
\text { associated }\end{array}$} & \multicolumn{2}{|c|}{$\begin{array}{l}1 \mathrm{M}-\mathrm{NaOH}- \\
\text { insoluble, cell- } \\
\text { associated }\end{array}$} \\
\hline & Glucan & Fructan & Glucan & Fructan & Glucan & Fructan \\
\hline MT8148R & $4.25 \pm 0.08$ & $0.75 \pm 0.07$ & $0.62 \pm 0.01$ & $0.09 \pm 0.01$ & $0.17 \pm 0.02$ & $<0.01$ \\
\hline MT6801R & $1.55 \pm 0.04$ & $1.95 \pm 0.01$ & $0.42 \pm 0.02$ & $0.03 \pm 0.01$ & $0.11 \pm 0.01$ & $<0.01$ \\
\hline NGl4 & $1.25+0.06$ & $0.60+0.10$ & $0.48+0.01$ & $<0.01$ & $0.09+0.01$ & $<0.01$ \\
\hline NG7183 & $0.95 \pm 0.11$ & $<0.01$ & $0.04 \pm 0.01$ & $<0.01$ & $0.10 \pm 0.01$ & $<0.01$ \\
\hline
\end{tabular}

Polysaccharides produced by $S$. mutans grown overnight in $1 \%(\mathrm{w} / \mathrm{v})$ sucrose broth were separated into three fractions and quantified (Table 2). All strains used produced extracellular, water-soluble glucan. Among these strains, the production of the glucan by strain MT8148R was very high. Furthermore, all strains except mutant $\mathrm{NG7183}$ produced $1 \mathrm{M}-\mathrm{NaOH}$-soluble, cellassociated glucan. The amount of extracellular, water-soluble fructan produced by strain MT6801R was lower than would be expected from the FTase activity detected (Tables 1 and 2). This result may be ascribed to the hydrolysis of fructan by fructanase and/or the difference of conditions of fructan synthesis. The fructan content of the $1 \mathrm{M}-\mathrm{NaOH}$-soluble, cell-associated polysaccharide was very low. No significant difference was observed among the strains with regard to $1 \mathrm{M}-\mathrm{NaOH}$-insoluble, cell-associated polysaccharide synthesis.

\section{Adherence of $S$. mutans}

Adherence of growing cells of serotype $c S$. mutans strains to a glass surface was determined. Values of percentage cell adherence of strains MT8148R, MT6801R, NG14 and NG7183 were $78.7 \pm 5.7,82.5 \pm 2.5,85.2 \pm 0.9$ and $3.3 \pm 0.9$ (mean \pm SD from triplicate cultures), respectively.

The kinetics of adsorption of $\left[{ }^{3} \mathrm{H}\right]$ thymidine-labelled resting cells $\left(2 \times 10^{8}\right)$ of $S$. mutans MT8148R to S-HA was examined. Adsorption of the cells to S-HA reached a maximum value after $30 \mathrm{~min}$ incubation in the absence of sucrose (Fig. 2). However, a $3 \mathrm{~h}$ incubation was required to achieve maximum adsorption in the presence of sucrose. Based on these results, the reaction mixtures were incubated for $3 \mathrm{~h}$ in subsequent experiments. As shown in Table 3, resting cells of all strains used attached similarly to S-HA in the absence of sucrose. However, addition of sucrose to the reaction mixture markedly enhanced the attachment of strains MT8148R, MT6801R and NG14, but had little effect on the attachment of mutant NG7183.

\section{Surface hydrophobicity}

The cell-surface hydrophobicity of serotype $c S$. mutans strains was determined by their adsorption to hexadecane and their aggregation in ammonium sulphate. The hydrophobicity of mutants NG14 and NG7183 was slightly higher than that of strains MT8148R and MT6801R.

\section{SDS-PAGE analysis of whole cells and culture supernatants}

SDS extracts of serotype $c S$. mutans strains were analysed by SDS-PAGE. Gels stained with Coomassie brilliant blue showed that mutant NG7183 did not possess a protein of $M_{\mathrm{r}} 160000$ (protein B) which was present in strains MT8148R, MT6801 R and NG14 (Fig. 3). Extracts of all the strains contained a high- $M_{\mathrm{r}}$ protein $\left(M_{\mathrm{r}} 200000\right.$; protein A). Strain MT6801R produced large amounts of extracellular proteins with $M_{\mathrm{r}}$ values of 96000 (protein C) and 83000 (protein 


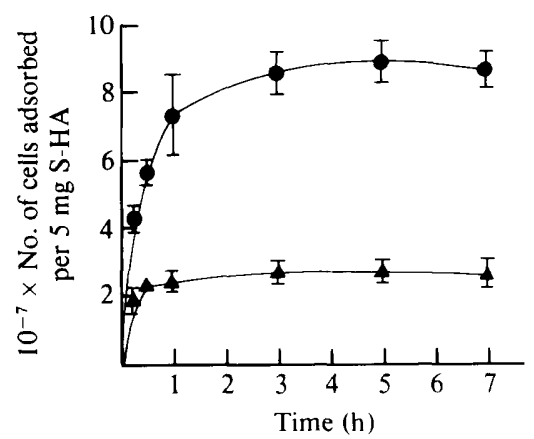

Fig. 2. Adsorption to S-HA of resting cells of $S$. mutans MT8148R. $\left[{ }^{3} \mathrm{H}\right]$ Thymidine-labelled bacteria (2 $\left.\times 10^{8}\right)$ were allowed to react with S-HA $(5 \mathrm{mg})$ in the presence $(\Theta)$ or absence $(\Lambda)$ of $1 \%(\mathrm{w} / \mathrm{v})$ sucrose for $15 \mathrm{~min}$ to $7 \mathrm{~h}$ at $37^{\circ} \mathrm{C}$.

Table 3. Adsorption to $S-H A$ of resting cells of serotype $c S$. mutans strains

$\left[{ }^{3} \mathrm{H}\right]$ Thymidine-labelled bacteria $\left(2 \times 10^{8}\right)$ were allowed to react with S-HA $(5 \mathrm{mg})$ in the presence or absence of $1 \%(\mathrm{w} / \mathrm{v})$ sucrose for $3 \mathrm{~h}$ at $37^{\circ} \mathrm{C}$. Values are the mean \pm SD of triplicate assays.

\begin{tabular}{|c|c|c|}
\hline \multirow{2}{*}{ Strain } & \multicolumn{2}{|c|}{$10^{-6} \times$ No. of cells adsorbed per $5 \mathrm{mg} \mathrm{S}-\mathrm{H}$} \\
\hline & Without sucrose & With sucrose \\
\hline $\begin{array}{l}\text { MT8148R } \\
\text { MT6801R } \\
\text { NG14 } \\
\text { NG7183 }\end{array}$ & $\begin{array}{l}25.4 \pm 3 \cdot 0 \\
25 \cdot 2 \pm 1 \cdot 1 \\
34.2 \pm 3 \cdot 2 \\
26.8 \pm 0.9\end{array}$ & $\begin{array}{l}87.3 \pm 5.1 \\
74.4 \pm 1.3 \\
96.9 \pm 7.8 \\
29.4 \pm 2.2\end{array}$ \\
\hline
\end{tabular}

D) (Fig. $4 a$ ) which produced fructan from sucrose (Fig. $4 b$ ) and raffinose (data not shown). In addition, several FTase bands were noted in this strain. On the other hand, no FTase band was detected in mutant NG7183. The quantity of the $M_{\mathrm{r}} 160000$ protein (protein B) produced by mutant NG7183 was much less than that of the same protein produced by strains MT8148R, MT6801R and NG14. The protein B band synthesized opaque white material from sucrose and reacted with anti-GTase-S monoclonal antibody (Fig. 4c), but did not synthesize polysaccharide from raffinose (data not shown). These results indicate that the protein B band is GTase.

\section{Acid production}

Acid production of serotype $c S$. mutans was determined in $1 \%(\mathrm{w} / \mathrm{v})$ glucose broth under aerobic and anaerobic conditions. Acid production by mutants NG14 and NG7183 was comparable to that by the parent strain (MT6801 R) and strain MT8148R in terms of final pH of the culture broth and concentration of lactate in the culture supernatant under both conditions (Table 5). No difference in relative growth rates of all the strains was detected under aerobic or anaerobic conditions.

\section{Cariogenicity and colonization ability}

Serotype $c S$. mutans strains were tested for their pathogenicity in specific-pathogen-free Sprague-Dawley rats reared on a high sucrose diet. Strain MT8148R and mutant NG14 induced significant dental caries, while strain MT6801 R, which produced a large amount of fructan, had diminished colonization ability and decreased cariogenicity as compared to strain MT8148R (Table 6). Mutant NG7183, which had lost the ability to form adhesive deposits on a glass surface in sucrose broth, was able to colonize the tooth surface of rats, but caused little decay. In addition, strains MT8148R, MT6801R and NG14 produced both smooth surface caries and fissure caries, but mutant NG7183 produced only fissure caries (data not shown). 


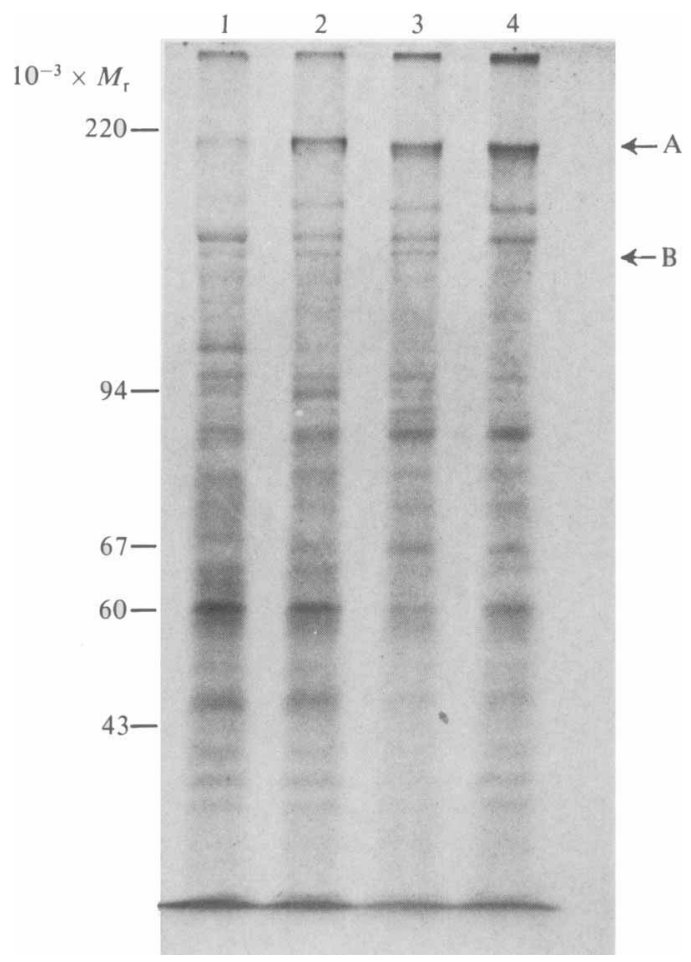

Fig. 3. SDS-PAGE of SDS extracts of serotype $c S$. mutans strains. Whole cells were suspended in $2 \%$ $(w / v)$ SDS and $1 \%(w / v) 2$-mercaptoethanol, and heated at $100^{\circ} \mathrm{C}$ for $30 \mathrm{~min}$. The SDS extract was clarified by centrifugation, and analysed by SDS-PAGE. The gel was stained with Coomassie brilliant blue. $M_{\mathrm{r}}$ markers used were ovalbumin $\left(M_{\mathrm{r}} 43000\right)$, catalase $(60000)$, bovine serum albumin $(67000)$, phosphorylase B (94000) and ferritin (220000). Lane 1, strain MT8148R; lane 2, strain MT6801R; lane 3 , strain NG14; lane 4, strain NG7183. Protein A is a high- $M_{\mathrm{r}}$ protein $\left(M_{\mathrm{r}} 200000\right)$; protein B is a GTase protein $\left(M_{\mathrm{r}} 160000\right)$.

\section{Table 4. Hydrophobicity of serotype $c S$. mutans strains}

Cells were grown in BHI broth. The relative surface hydrophobicity of the cells was determined by their adsorption to hexadecane and their aggregation in salt. The bacterial suspension $(3 \mathrm{ml})$ was mixed with $300 \mu \mathrm{l}$ hexadecane. Adsorption was calculated as the percentage loss in optical density relative to that of the initial cell suspension (see Methods). The value of salt aggregation ability represents the lowest ammonium sulphate concentration (M) causing bacterial aggregation. Values are the mean \pm SD of triplicate assays.

$\begin{array}{lcc}\text { Strain } & \begin{array}{c}\text { Bacteria adsorbed } \\ \text { to hexadecane }\end{array} & \begin{array}{c}\text { Bacterial } \\ \text { aggregation } \\ \text { (M) }\end{array} \\ \text { MT8148R } & 27 \cdot 2 \pm 4 \cdot 7 & 1 \cdot 2 \\ \text { MT6801R } & 21 \cdot 1 \pm 2 \cdot 0 & 1 \cdot 2 \\ \text { NG14 } & 38 \cdot 3 \pm 3 \cdot 6 & 1 \cdot 1 \\ \text { NG7183 } & 32 \cdot 7 \pm 3 \cdot 8 & 1 \cdot 1\end{array}$

\section{DISCUSSION}

$S$. mutans adheres to tooth surfaces by sucrose-independent and sucrose-dependent mechanisms. The former mechanism is via electrostatic, lectin-like and hydrophobic interactions, and hydrogen bonding (Gibbons, 1984), whereas the latter is due to de novo 

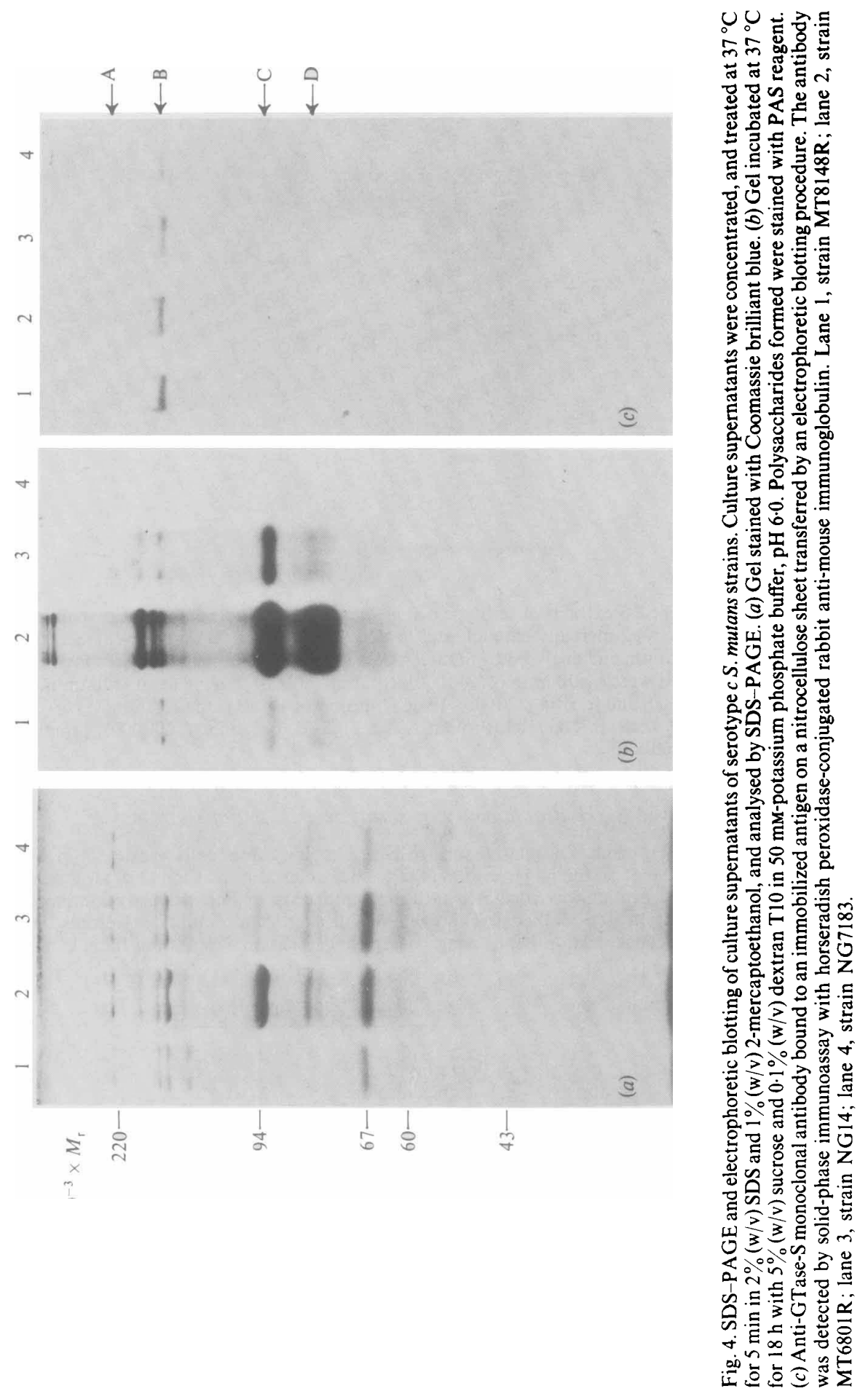
Table 5. Acid production by serotype $c$ S. mutans strains

Cells were grown aerobically and anaerobically in BHI broth containing $1 \%(\mathrm{w} / \mathrm{v})$ glucose for $48 \mathrm{~h}$ at $37^{\circ} \mathrm{C}$. Values are the mean \pm SD of triplicate cultures.

\begin{tabular}{|c|c|c|c|c|c|c|}
\hline \multirow[b]{2}{*}{ Strain } & \multicolumn{2}{|c|}{$\begin{array}{l}\text { Growth } \\
\left(O_{550}\right)\end{array}$} & \multicolumn{2}{|c|}{ Final $\mathrm{pH}$} & \multicolumn{2}{|c|}{$\begin{array}{l}\text { Lactate production } \\
{\left[\mu \mathrm{mol}(\mathrm{ml} \text { culture })^{-1}\right]}\end{array}$} \\
\hline & Aerobic & Anaerobic & Aerobic & Anaerobic & Aerobic & Anaerobic \\
\hline MT8148R & $3 \cdot 0 \pm 0 \cdot 3$ & $2.8 \pm 0.4$ & $4 \cdot 2 \pm 0 \cdot 1$ & $4 \cdot 0 \pm 0 \cdot 2$ & $45 \cdot 2 \pm 5 \cdot 0$ & $51.4 \pm 2.7$ \\
\hline MT6801R & $3 \cdot 0 \pm 0 \cdot 1$ & $2.7 \pm 0.4$ & $4 \cdot 2 \pm 0 \cdot 1$ & $4 \cdot 1 \pm 0 \cdot 1$ & $45 \cdot 0 \pm 5.9$ & $52 \cdot 7 \pm 2 \cdot 0$ \\
\hline NGl4 & $2 \cdot 9 \pm 0.3$ & $2.7 \pm 0.2$ & $4.3 \pm 0.1$ & $4 \cdot 1 \pm 0 \cdot 1$ & $42.7 \pm 5.7$ & $50 \cdot 2 \pm 1.8$ \\
\hline NG7183 & $2 \cdot 8 \pm 0.3$ & $2.7 \pm 0.3$ & $4.3 \pm 0.2$ & $4 \cdot 2 \pm 0 \cdot 1$ & $48.9 \pm 3.0$ & $48.4 \pm 1.8$ \\
\hline
\end{tabular}

Table 6. Cariogenicity of serotype c S. mutans strains in specific-pathogen-free Sprague-Dawley rats

\begin{tabular}{|c|c|c|c|}
\hline Strain & $\begin{array}{l}\text { No. of } \\
\text { rats }\end{array}$ & $\begin{array}{l}\text { Caries score } \\
\text { (mean } \pm \text { SD) }\end{array}$ & $\begin{array}{c}\text { Recovery of } S . \text { mutans } \\
{[\log \text { (c.f.u.) }} \\
(\text { mean } \pm \text { SD) }]\end{array}$ \\
\hline MT8148R & 10 & $23.9 \pm 7.4$ & $6.73 \pm 0.43$ \\
\hline MT6801R & 11 & $17.7 \pm 2.8$ & $4.73 \pm 0.44$ \\
\hline NG 14 & 10 & $25.1 \pm 7.7$ & $6.31 \pm 0.56$ \\
\hline NG7183 & 11 & $1.7 \pm 1.6$ & $4.17 \pm 0.57$ \\
\hline None & 12 & $1.8 \pm 1.3$ & 0 \\
\hline
\end{tabular}

synthesis of water-insoluble glucan by GTases from sucrose (Hamada \& Slade, 1980). In this study, we isolated from $S$. mutans MT6801R (serotype $c$ ) a mutant, NG7183, that formed small, smooth colonies on MS agar. We found that mutant NG7183 could not adhere to a glass surface in sucrose broth, although the mutant was able to colonize the surfaces of teeth in vivo. Clearly, there is some disparity between in vitro sucrose-dependent adherence and in vivo adherence, indicating that sucrose-dependent adherence does not appear to be the whole story in in vivo experiments. Whole cells of mutant NG7183 attached to S-HA in the absence of sucrose, suggesting that serotype $c S$. mutans can colonize the surfaces of teeth by a sucrose-independent mechanism. However, its attachment was enhanced in the presence of sucrose. In addition, mutant NG7183 failed to cause dental caries in spite of having the same ability to produce acid and the same growth rate as strains MT8148R, MT6801R and NG14. These results imply that the sucrose-dependent adherence is required for caries induction by serotype $c S$. mutans.

Recently, the role of cell-surface hydrophobicity in mediating bacterial adherence to host surfaces has received considerable attention by many investigators (Olsson \& Westergren, 1972; Nesbitt et al., 1982; Weiss et al., 1982; Westergren \& Olsson, 1983). Gibbons \& Etherden (1983) reported that highly hydrophobic oral bacteria attach in significantly higher numbers to experimental pellicles than do less hydrophobic or hydrophilic bacteria. McBride et al. (1984) have indicated that hydrophobic $S$. mutans strains possess a protein of $M_{\mathrm{r}} 190000$, similar to antigen I/II (Russell et al., 1980) and antigen B (Russell, 1979b), in the cell wall. In this study, the hydrophobicity of mutants NG14 and NG7183 and their ability to attach to S-HA in the absence of sucrose was slightly higher than that of the parent strain MT6801R (Tables 3 and 4). SDS extracts from whole cells of all strains used in this study contained the high- $M_{\mathrm{r}}$ protein (Fig. 3 ), which was confirmed by the electrophoretic blotting method to react with anti-antigen $B$ serum (data not shown). The increase of hydrophobicity of the mutants may result from exposure of new hydrophobic components due to a change in the hydrophilic proteins on the cell surfaces.

The high-fructan-producing strain MT6801R adhered firmly to a glass surface in sucrose broth. However, the number of cells of strain MT6801R that adsorbed to experimental pellicles 
in the presence of sucrose was lower than that of strains MT8148R and NG14. In addition, strain MT6801R had lower colonization ability and cariogenicity when compared with strains MT8148R and NG14 (Table 6). These results suggest that fructan is unable to act as a mediator in the attachment and accumulation of $S$. mutans to tooth surfaces or as a barrier to prevent the diffusion of acids produced by the organism. The decrease in the colonization ability and cariogenicity of strain MT6801 R might be attributable to production of large amounts of fructan as well as water-insoluble glucan. The presence of significant amounts of fructan in waterinsoluble glucan may disturb firm adherence of the glucan to the tooth surface, since fructan can be easily removed by dissolving in saliva.

In summary, the present results indicate (i) that serotype $c S$. mutans adheres to tooth surfaces by sucrose-independent and sucrose-dependent mechanisms, (ii) that the sucrose-dependent adherence is required for caries induction by serotype $c S$. mutans, as well as serotype $d$ and $g$ strains and (iii) that fructan does not act as a virulence factor of serotype $c S$. mutans.

\section{REFERENCES}

Adelberg, E. A., Mandel, M. \& Chen, G. C. C. (1965). Optimal conditions for mutagenesis by $N$ methyl- $N^{\prime}$-nitro- $N$-nitrosoguanidine in Escherichia coli K12. Biochemical and Biophysical Research Communications 18, 5-6.

BURNETTE, W. N. (1981). "Western blotting": electrophoretic transfer of proteins from sodium dodecyl sulfate-polyacrylamide gels to unmodified nitrocellulose and radiographic detection with antibody and radioiodinated protein A. Analytical Biochemistry 112, 195-203.

Cohen, B., Peach, S. L. \& Russell, R. R. B. (1983). Immunization against dental caries. Medical Microbiology 2, 255-294.

Eifert, R., Rosan, B. \& Golub, E. (1984). Optimization of an hydroxyapatite adhesion assay for Streptococcus sanguis. Infection and Immunity 44, $287-291$

Fives-Taylor, P. M. \& Thompson, D. W. (1985). Surface properties of Streptococcus sanguis FW213 mutants nonadherent to saliva-coated hydroxyapatite. Infection and Immunity 47, 752-759.

Freedman, M. L. \& Tanzer, J. M. (1974). Dissociation of plaque formation from glucan-induced agglutination in mutants of Streptococcus mutans. Infection and Immunity 10, 189-196.

Furuta, T., Nisizawa, T., Chiba, J. \& Hamada, S. (1983). Production of monoclonal antibody against a glucosyltransferase of Streptococcus mutans 6715. Infection and Immunity 41, 872-875.

GibBONS, R. J. (1984). Adherent interaction which may affect microbial ecology in the mouth. Journal of Dental Research 63, 378-385.

Gibbons, R. J. \& Etherden, I. (1983). Comparative hydrophobicities of oral bacteria and their adherence to salivary pellicles. Infection and Immunity 41, 11901196

Gutman,, I. \& Wahlefeld, A. W. (1974). L- (+)Lactate; determination with lactate dehydrogenase and NAD. In Methods of Enzymatic Analysis, vol. 3, pp. 1464-1468. Edited by H. U. Bergmeyer. New York \& London: Academic Press.

Hamada, S. (1977). New glucan synthesis as a prerequisite for adherence of Streptococcus mutans to smooth surfaces. Microbios Letters 5, 141-146.
Hamada, S. \& Slade, H. D. (1980). Biology, immunology, and cariogenicity of Streptococcus mutans. Microbiological Reviews 44, 331-384.

Hamada, S., Toril, M., Kotani, S. \& Tsuchitani, Y. (1981). Adherence of Streptococcus sanguis clinical isolates to smooth surfaces and interaction of the isolates with Streptococcus mutans glucosyltransferase. Infection and Immunity 32, 364-372.

HANDEL, E. V. (1967). Determination of fructose and fructose-yielding carbohydrates with cold anthrone. Analytical Biochemistry 19, 193-194.

KEYES, P. H. (1944). A method of recording and scoring gross carious lesions in the molar teeth of Syrian hamsters. Journal of Dental Research 23, 439444.

KeYeS, P. H. \& Jordan, H. V. (1964). Periodontal lesions in the Syrian hamster. III. Findings related to an infectious and transmissible component. Archives of Oral Biology 9, 377-400.

KoGa, T. \& INoue, M. (1978). Cellular adherence, glucosyltransferase adsorption, and glucan synthesis of Streptococcus mutans AHT mutants. Infection and Immunity 19, 402-410.

KoGA, T. \& INOUE, M. (1981). Inactivation of Dglucosyltransferases of oral Streptococcus mutans and Streptococcus sanguis by photochemical oxidation. Carbohydrate Research 93, 125-133.

LAEMMLI, U. K. (1970). Cleavage of structural proteins during the assembly of the head of bacteriophage T4. Nature, London 227, 680-685.

MCBride, B. C., Song, M., Krasse, B. \& Olsson, J. (1984). Biochemical and immunological differences between hydrophobic and hydrophilic strains of Streptococcus mutans. Infection and Immunity 44, 6875.

Mukasa, H. \& Slade, H. D. (1973). Mechanism of adherence of Streptococcus mutans to smooth surfaces. I. Roles of insoluble dextran-levan synthetase enzymes and cell wall polysaccharide antigen in plaque formation. Infection and Immunity 8,555 562.

Nesbitt, W., Doyle, R. J. \& TAyloR, K. G. (1982). Hydrophobic interaction and the adherence of Streptococcus sanguis to hydroxylapatite. Infection and Immunity 38, 637-644. 
OKahashi, N., Asakawa, H., Koga, T., Masuda, N. \& Hamada, S. (1984). Clinical isolates of Streptococcus mutans serotype $c$ with altered colony morphology due to fructan synthesis. Infection and Immunity 44, 617-622.

OlsSON, J. \& WestergRen, G. (1972). Hydrophobic surface properties of oral streptococci. FEMS Microbiology Letters 15, 319-323.

Ooshima, T., Izumitani, A., Sobue, S., OKahashi, N. \& Hamada, S. (1983). Non-cariogenicity of the disaccharide palatinose in experimental dental caries of rats. Infection and Immunity 39, 43-49.

Rosenberg, M., Gutnick, D. \& Rosenberg, E. (1980). Adherence of bacteria to hydrocarbons: a simple method for measuring cell-surface hydrophobicity. FEMS Microbiology Letters 9, 29-33.

Russell, M. W., Zanders, E. D., Bergmeier, L. A. \& LEHNER, T. (1980). Affinity purification and characterization of protease-susceptible antigen I of Streptococcus mutans. Infection and Immunity 29, 9991006.

RuSSELL, R. R. B. (1979a). Glucosyltransferases of Streptococcus mutans strain Ingbritt. Microbios 23, 135-146.

RUSSELL, R. R. B. (1979b). Wall-associated protein antigens of Streptococcus mutans. Journal of General Microbiology 114, 109-115.

Sato, S., Koga, T. \& Inoue, M. (1984). Isolation and some properties of extracellular D-glucosyltransferases and D-fructosyltransferases from Streptococcus mutans serotypes $c, e$, and $f$. Carbohydrate Research 134, 293-304.

Smith, D. J. \& Taubman, M. A. (1977). Antigenic relatedness of glucosyltransferase enzymes from Streptococcus mutans. Infection and Immunity 15, 91103.

Tsumori, H., Shimamura, A. \& Mukasa, H. (1983). Comparative study of Streptococcus mutans extracellular glycosyltransferases by isoelectric focusing. Journal of General Microbiology 129, 3261-3269.

Weiss, E., Rosenberg, M., Judes, H. \& Rosenberg, E. (1982). Cell-surface hydrophobicity of adherent oral bacteria. Current Microbiology 7, 125-128.

Westergren, G. \& Olsson, J. (1983). Hydrophobicity and adherence of oral streptococci after repeated subculture in vitro. Infection and Immunity 40, 432435.

YaKushiJi, T., Inoue, M. \& Koga, T. (1984). Interserotype comparison of polysaccharides produced by extracellular enzymes of Streptococcus mutans. Carbohydrate Research 127, 253-266.

Zacharius, R. M., ZeLl, T. E., Morrison, J. H. \& WOODLOCK, J. J. (1969). Glycoprotein staining following electrophoresis on acrylamide gels. Analytical Biochemistry 30, 148-152. 